University of Michigan Law School

University of Michigan Law School Scholarship Repository

Articles

Faculty Scholarship

1922

\title{
Privity of Contract and Tort Liability
}

\author{
Herbert F. Goodrich \\ University of Michigan Law School
}

Available at: https://repository.law.umich.edu/articles/1556

Follow this and additional works at: https://repository.law.umich.edu/articles

Part of the Contracts Commons, State and Local Government Law Commons, and the Torts

Commons

\section{Recommended Citation}

Goodrich, Herbert F. "Privity of Contract and Tort Liability." Mich. L. Rev. 21 (1922): 200-3.

This Response or Comment is brought to you for free and open access by the Faculty Scholarship at University of Michigan Law School Scholarship Repository. It has been accepted for inclusion in Articles by an authorized administrator of University of Michigan Law School Scholarship Repository. For more information, please contact mlaw.repository@umich.edu. 


\section{Michigan LaW Review}

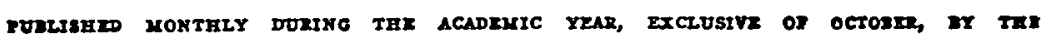
LAW SGHOOL OF THE UNIVERSTY OF MICHICAN

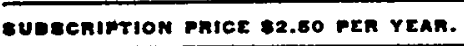
So cents pen mukern

JOHN BARKER WAITE, EDITOR-IN-ChIEF ASSOCIATE EDITORS

HENRY M. BATES

RAIPE W. AIGLìR

EDwin D. Dickinson

EDSON R. SUNDERLAND Burke Sharteri,

STUDENTS, APPOINTED BY THE FACULTY

William H. Bales, of Indiana

JOHN W. BIRD, of Michigan

Harold A. Jones, of Michigan

George W. Manderbach, of Pennsylvania

Clyde Y. Morris, of New Mexico

EARL F. BOXELL, of Indiana

William E. Burby, of Michigan

George DammanN, of Illinois

ARTHur F. NEzF, of Michigan

Frank M. PARrISH, of Pennsylvania

Elwy G. Davies, of Ohio

Ronald M. Ryan, of Michigan

John P. Dawsnn, of Michigan

Milton J. SAllwasser, of Indiana

BOWEN E. SCHUMACHER, of Illinois

ALLARD W. Frogner, of Wisconsin

BENJAAIN T. SMITF, of Michigan

Giry T. Grayrs, of Nehraska

BECHER W. HUNGERFORD, of Michigan

Gladrs WezLs, of North Carolina

THOMAS J. WHINERY, of Michigan

FrbDERICK P. WYNN, of North Dakota

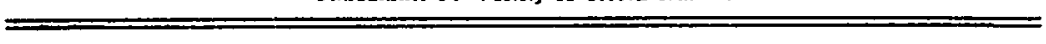

\section{NOTE AND COMMENT'}

Privity of Contract and Tort Imability.-Two parties, $A$ and $B$, make a contract whereby $B$ undertakes to perform certain services for $A$. He performs his task in a negligent manner, and as a consequence $C$, a third party, suffers injury. Has $C$ rights against $B$ ?

No one disputes the soundness of the general proposition that to recover for the consequences of a negligent act the plaintiff must be one to whom the actor owed a duty to be careful. (See Lord Esher in Le Lievre v. Gould [1893], I Q. B. D. 49I, 497, and Mitchell, J., in Akers v. Chicago, etc., R. Co., 58 Minn. 540, 544). Subject to exceptions not important here, $C$, a stranger to the contract, gains no rights from it. That transaction is as to him res inter alios acta. But if C's rights are not enlarged by the consensual transaction between $A$ and $B$, they surely are not restricted by it. For a full discussion of the subject, going beyond the range of this note, see $F$. $H$. Bohlen, "Affirmative Obligations in the Iraw of Tort" 44 AMER L. REG. (n. s.) $209,273,337$.$) To affect a little more law Latin, res inter alios acto$ alteri nocere non debet. C's rights will depend on the general rules of tort 
liability, and may even be broader than obligations owed $A$ by $B$ under the contract. (See, for instance, Barrett $v$. Lake Ontario Beach Imp. Co., 174 N. Y. 3To; Junkermann v. Jankelson, 213 N. Y. 405; I. R. A. I915 F 700 and note.) If $A$ hired $B$ to drive his delivery truck, and in the course of the business $B$ carelessly ran over $C$, no one would doubt B's liability. The case seems equally clear for $C$ where the contract between $A$ and $B$ calls for the doing of something to C, performing a surgical operation upon him, for instance. If $\mathrm{B}$ does it carelessly and injures $\mathrm{C}, \mathrm{C}$, may recover. DuBois v. Decker, I30 N. Y. 325 ; Gladwell v. Steggall, 5 Bing. (N. C.) 733. So if A pays the B railroad to carry C, Seybolt $v . N$. Y., etc., $R$. Co., 95 N. Y. 562, or his baggage, Marshall v. York, etc., Ry. Co, II C. B. 655, and person or property is hurt, $\mathrm{C}$ may recover, though a stranger to the contract. Clearly $C$ should recover, for the defendant would be made liable for his carelessness, even where no contract existed. Becker $v$. Janinski, I5 N. Y.

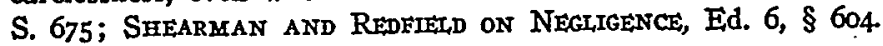

In general, the law imposes no duty to act affirmatively to benefit a stranger. But there are plenty of instances in the books where one who, though not obliged to act, undertakes to do so, and does it carelessly, is liable for the injuries he causes. (Not for failing to confer a benefit which he has agreed, without consideration, to grant, but for the careless act he does which causes harm. See Gill $v$. Middletun, Io5 Mass. 477; Black v. N. Y., etc., R. Co., 193 Mass. 448.) The plaintiff's rights are no less, surely, because this careless act was also a violation of a contract between the actor and some third party. These are but instances of the general rule of liability for consequences of negligent acts. The defendant is liable if, as a man of reasonable prudence, he should have foreseen the likelihood of danger to others in the act he did and at the time at which he did it. What a person may reasonably anticipate is important in considering whether he has been negligent. The duty to take care is owed to persons within the probable range of the forces he sets in motion. Blackburn, J., in Smith $v$. L. \& $S . W . R y$. Co., L. R. 6 C. P. I4. This ought to be equally true whether the act done be to shoot a gun, wield a scalpel, or to disseminate information. "When a responsible defendant seeks to escape from liability for an act which he had noticed was likely to cause temporal damage to another, and which has caused such damage in fact, he must show a justification." Mr. Justice Holmes in 8 HARv. L. REv., on page 9.

If all this is so, the recent New York case of Glonzer $v$. Shepard, 233 N. Y. 236,135 N. E. 275 , is unusual only in the neat way in which facts presented the question for decision and the particularly straightforward and understanding manner in which the court, speaking through Cardozo, J., met the issue. The facts may be put in the terms of the hypothetical case at the beginning of this discussion. A employed $\mathrm{B}$, who was in business as a public weigher, to weigh a quantity of beans; payment for the service was made by $A$. B knew that $C$ had purchased the beans from $A$, and at A's request furnished $C$ a duplicate copy of the weight certificate. The weight was incorrectly reported, owing to negligence on B's part. C paid $A$ for the beans the amount called for by the weight shown in the certif- 
cate, and upon discovering that he had paid for more beans than he received sued $B$ for the difference in value between what he got and what he was supposed to have received according to the certificate. The court held that he was entitled to recover on the ground of violation of a duty imposed by lavr. "Diligence was owing, not only to him who ordered, but to him also who relied."

It could hardly be claimed, however, that the law has reached a state of logical consistency in the application of the basic rules regarding negligence. Instance the almost innumerable cases on the liability of a manufacturer of a chattel whose negligence in its making has caused injury to the consumer for whose use it was made. Starting out by denying liability,

" courts have given a consumer increasing protection by building up exceptions while still rendering lip service to the former rule. There is a full discussion of the origin. and development of this doctrine and a criticism thereof in the articles by Professor Bohlen, supra. Only recently has this protection been based on fundamental principles of tort liability. Macpherson v. Buick Motor Co., 217 N. Y. 382, L. R. A. I916 F 696; commented upon in 29 HARV. L. REV. 866. And we still have enunciation of the old rule and its exceptions by courts of authority and learning. Pitman v. Lymn Gas and Elect. Co. (Mass.), I35 N. E. 223; Liggett \& Myers Tobacco Co. v. Cannon (Tenn.), $178 \mathrm{~S}$. W. I009; the latter commented upon in 14 Micr. 2. REv. $\mathrm{I}_{\overline{6}}$.

Closer to the situation presented in Glanzer $v$. Shepard are those cases where $B$ has been employed under contract to furnish information to $A$, and where $\mathbf{C}$ has relied to his damage on the information that $\mathrm{B}$ has negligently furnished. Authority says that $C$ cannot recover. Some of the decisions could easily be placed on the ground that $B$ did not know nor could he be expected to know that $\mathrm{C}$ would rely on his statements. Savings Bank v. Ward, 100 U. S. 195. In others, however, B knew that strangers to the contract would be influenced by the information rendered to $C$. Lassdell v. Lybrand ( $\mathrm{Pa}$.), IO7 At1. 783; comment in 29 YAIE L. Jour, 234; Le Lievre $v$. Gould [1893], I Q. B. D. 49I. In some instances there was even shown a custom to this effect. Gordon v: Livingston, I2 Mo. App. 267; Kahl v. Love, 37 N. J. L. 5. Cf., as to abstractor, Anderson v. Spriestersbach, 69 Wash. 393, 42 L. R. A. (n. s.) I76 and note.

Stress is laid, in the opinions, upon the recessity of a duty between the parties before recovery can be had by one for consequences of negligent acts of the other. Then it seems to be assumed, rather than proved, that there is no duty, except to a party to the contract, other than that to refrain from intentional harm. This is a hasty assumption. Professor Bohlen suggests that perhaps analogies of the law of deceit and high regard to the freedom of speech have contributed to the result (page 373 of the articles referred to). Perhaps so; though it is to be noted that the law of deceit itself is developing in the direction of stricter liability. See Williston, "Liability for Honest Misrepresentation," 24 HARV. L. REV. 415. And immunity for the defendant here cannot rest upon the castual nature of the service rendered. Surely a public accountant, weigher or abstractor would resent an imputa- 
tion that his reports were so unreliable as not to be worthy of reliance by anyone except the one party who contracted for the service. Somewhere a line must be drawn. It is not every casual statement that should render the maker liable if its incorrectness leads another to harm. See Judge Smith's interesting article on "Liability for Negligent Ianguage," I4 HaRv. L. REV. 184. But where a supposed expert makes a statement upon which he knows others will act, and damage ensues because the statement was carelessly made, it is hard to see why a defense of lack of privity of contract should shield the maker.

The instant case marks a step forward. Not only does it make for logical consistency in the law of torts; it helps to bring the law on this point into harmony with the facts of life. Here, it would seem, philosophy and sociology speak with the same voice. (CArDozo, The NATURE of THE JUdICIAL Process, Lecture 2.) Coming as it does from one of our strongest and most eminent courts, the decision should have its effect on the law.

H. F. G.

i

